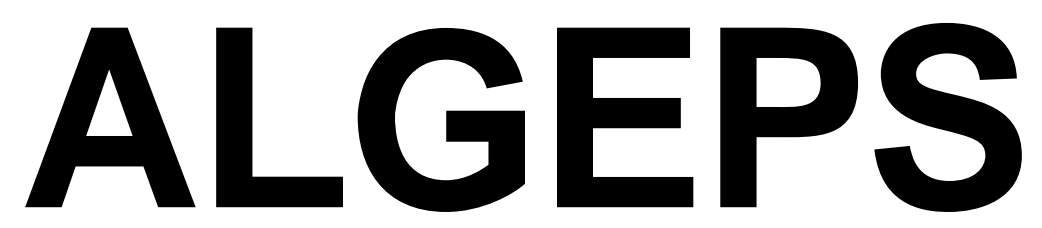

REVISTA DE GEOLOGIA, SÈRIE B no 613 - Gener del 2013

\title{
RECORREGUT DE RECERCA GEOLÒGICA I MINERALÒGICA PER LES COMARQUES DEL BAGES DEL MOIANÈS I D'OSONA: DES DE MANRESA A MOIÀ, COLLSUSPINA, SANT CUGAT DE GAVADONS \\ I A TONA
}

Josep M. Mata-Perelló i Joaquim Sanz Balagué

Aquest recorregut va ésser experimentat amb docents el dia 1 DE MAIG DEL 2011 


\title{
RECORREGUT DE RECERCA GEOLÒGICA I MINERALÒGICA PER LES COMARQUES DEL BAGES DEL MOIANÈS I D'OSONA: DES DE MANRESA A MOIÀ, COLLSUSPINA, SANT CUGAT DE GAVADONS I A TONA
}

\author{
Per Josep M. MATA-PERELLÓ i Joaquim SANZ BALAGUÉ
}

\section{ADVERTIMENT PREVI}

Com en altres recorreguts de RECERCA GEOLÒGICA I MINERALÒGICA ..., si es disposa del temps suficient, poden efectuar-se passant per totes les parades i filloles. En cas contrari, recomanem prescindir de les anomenades PARADES - CONDICIONALS.

Pel que fa als camins per on transitarà el recorregut de l'itinerari, cal dir que en general es trobaran en bones condicions. Tot i així, sempre que sigui possible, recomanem demanar la màxima informació, en relació al estat real dels camins. En cas de trobar-se en males condicions, recomanem fer el desplaçament a peu. Així en aquest recorregut, hi ha un recorregut per camins de terra per tal d'anar cap a la Font de les Tàpies; així com altres recorreguts més curts, al llarg de l'itinerari general.

En qualsevol cas, cal tenir una cura molt especial de respecte a la natura, al llarg de tot el recorregut; de l'itinerari.

\section{BREU INTRODUCCIÓ}

En aquesta ocasió, el recorregut de 1'itinerari que ara presentem discorrerà, en la seva totalitat per la Depressió Geològica de l’Ebre (i més concretament pel seu sector corresponent a la seva Depressió Central).

Per d'altra banda, en diverses aturades del recorregut, si s'escau, es faran observacions a distancia d'altres unitats geològiques, tant del Sistema Mediterrani. (i més concretament dintre de la seva Serralada Prelitoral Catalana); com també del Sistema Pirinenc. Tanmateix, visionarem a distancia altres sectors de la pròpia Depressió Geològica de l'Ebre, com els Altiplans Meridionals; o de la Serralada Transversal.

Per d'altra banda, el recorregut de l'itinerari discorrerà per les comarques del Bages i d'Osona. Tot i així, entre ambdues, també ho farà per la subcomarca del Moianès. Així, dintre d'aquesta darrera, circularem exclusivament pels seus sectors septentrionals (concretament: pels bagencs i pels osonencs). Finalment, cal dir que el recorregut s'iniciarà a la comarca del Bages, per a finalitzar a la comarca d'Osona (dintre de la seus sectors corresponents a l'esmentada subcomarca del Moianès). 


\section{OBJECTIUS FONAMENTALS}

Els objectius d’aquest itinerari, es centraran, fonamentalment, en els següents aspectes, d'acord amb el sentit de la marxa:

1.- S'observarà l'estructura de la Depressió Geològica de l'Ebre (i més concretament del seu sector de la Depressió Central), per la qual circularà al llarg de tot el recorregut de l'itinerari, entre les localitats de Manresa i de Tona. Per d'altra banda, També es faran observacions a distancia d'altres sotsunitats que formen part de l'esmentada Depressió Geològica de l'Ebre; en concret dels Altiplans Meridionals (de Montserrat, del Montcau, i de Sant Llorenç de Munt), des de les parades situades al Malvals (Manresa), i a l'Estació de Servei (de Calders), així com des del Port de la Pullosa (Collsuspina); i de la Serralada Transversal Catalana (concretament del Cabrerès), que efectuarem tant des de l'esmentada Estació de Servei (de Calders), com d'altres indrets del recorregut.

2.- Es reconeixeran els materials cenozòics que constitueixen el rebliment de la Depressió Central. per aquests indrets. Aquests materials, eminentment eocènics, i de caràcter detrítit, es reparteixen entre els afloraments que pertanyen a les següents unitats litoestratigráfiques: Formació Igualada, Formació Tossa (dintre d’aquesta, també veurem els nivells dels Guixos d'Òdena, i els dels Guixos de la Noguera, a certa distancia). Finalment, tanmateix veurem els materials de la Formació Artés, en bona part del recorregut.

3.- .També es faran observacions a distancia dels sectors corresponents als Prepirineus (del sectors meridionals del Sistema Pirinenc), fonamentalment des de la parada que realitzarem a l’Estació de Servei de Calders.

4.-.Si s'escau, s'estudiaran algunes mineralitzacions distribuïdes al llarg del recorregut. Així, es veuran, les següents:

4A) les mineralitzacions evaporítiques de caràcter guixòs, les quals es veuran a distancia. Es situen entre els afloraments de la Formació Tossa, i més concretament, dintre dels nivells dels Guixos de la Noguera.

4B) les mineralitzacions cupriferes associades a "red-beds", que si s'escau veurem a Ferrerons, entre els trams de nivells carbonatats intercalats entre els nivells de gresos i calcolutites rogenques de la Formació Artés

5.- Observació de diferents explotacions mineres, antigues i més recents, relacionades amb les mineralitzacions esmentades a l'apartat anterior. Concretament, de les següents:

5A) de les antigues explotacions de calcàries, adreçades als Forns de Calç (com el que veurem prop de la Font de les Tàpies).

5B) de les antigues guixeres de Tona, situades entre els nivells dels Guixos de la Noguera, dintre de la Formació Tossa.

6.- Observació de les alteracions produïdes sobre el Medi Natural, tant a partir de les explotacions acabades d'esmentar, com de la construcció de grans vials de comunicació (com 1'Eix Transversal), o com de les explotacions agrícoles.

7.- Observació de diversos indrets relacionats amb el nostre Patrimoni Geològic, entre els quals destaquen els següents:

7A) de la Font de les Tàpies, situada entre les calcàries de la Formació Tossa, que trobarem entre les poblacions de Sant Fruitós de Bages i Calders. 
7B) del meandre de Calders, descrit pel riu del mateix nom, prop de la Urbanització de la Guàrdia, a Calders

7C) de la important Cova del Toll (i de la propera Cova de les Toixoneres), situada també entre les calcàries de la Formació Tossa, al terme de Moià.

8.- Observació de diferents indrets relacionats amb el nostre Patrimoni Miner, entre els quals cal fer esment de les instal-lacions de l'àntic Forn de Calç (que trobarem prop de la Font de les Tàpies).

\section{ANTECEDENTS BIBLIOGRÀFICS}

Com antecedents parcials del recorregut del present itinerari, farem esment de diversos treballs nostres, corresponents a altres itineraris, concretament dels següents: MATA-PERELLÓ (1996, 1997, 1999a, 1999b, 2000, 2005, 2006, 2008 i 2011), aquests dos darrers són uns itineraris força coincident amb el que ara presentem.. També farem esment d'altres itineraris, de: MASACHS et altri (1981), y de MATA-PERELLÓ i SANZ BALAGUÉ (1988). En alguns indrets, coincideixen parcialment amb el recorregut del present itinerari.

També farem esment del treball, corresponent a altres itineraris, de: BUSQUETS et altri (1979), que inclou recorreguts pels sectors oriental de la comarca d'Anoia, per on discorre part del recorregut del present itinerari.

Com antecedents de caire general, corresponents als trets geològics bàsics, considerarem els treballs de: GUIMERÀ et altri (1992), així com el de RIBA (1976). També el de BARNOLAS et altri (1986), corresponent a fulls geològics, per on discorre la major part de l'itinerari. Igualment, farem esment del treball monogràfic de COLLDEFORNS (1986), corresponent a la geologia de la comarca del Bages. Finalment farem esment d'altres treballs com: MATA-PERELLÓ (1986) i RIBA et altri (1967). Igualment farem esment dels treballs de l“IGME (1974 i 1982), relatius a les memòries dels fulls geològics per on discorre el present recorregut.

Dintre dels caràcters mineralògics dels indicis per on discorrerà l'itinerari, farem esment d'un antecedent mineralògic general, referit a l'àmbit de Catalunya: MATA-PERELLÓ (1991). Igualment es pot esmentar el treballs de MATA-PERELLÓ i COLLDEFORNS (1988). Aquest darrer te caràcter comarcalista, referint-se a les comarca del Bages, per on discorrerà par del recorregut de l'itinerari.

Tots aquests treballs, i d'altres, es trobaran relacionats a l'apartat dedicat a les REFERÈNCIES BIBLIOGRÀFIQUES, al qual ens remetem.

\section{RECORREGUT DE L'ITINERARI}

El recorregut de l'itinerari s'iniciarà a Manresa, i més concretament al Polígon Industrial de Bufalvent (situat sobre el Malvals), on es farà la primera aturada. Després de fer-la, caldrà circular per la variant de Manresa, per tal d'agafar la carretera N-141c, en el seu sentit cap oriental, cap a Vic. 
En arribar, per aquesta carretera al trencall de la Colònia Jorba (situat a la dreta de la ruta principal), cal agafar el camí que surt per l'altra banda de la carretera, per tal d'anar per un cap a la Font de les Tàpies, on es faria una nova parada. Cal fer esment de que aquest camí te diversos trams que no es troben en bon estat de conservació. Des d'aquí, es continuaria pel camí de terra, per tal d'anar a trobar la carretera que es dirigeix des d'Artés cap a Calders. En trobarla es faria una altra aturada. Després, s’aniria cap a la Urbanització de la Guàrdia de Calders, per tal de sortir de nou a la carretera N-141c, fent-se una nova aturada prop del seu Km 16, poc després d'haver-la trobat, i d'haver anat lleugerament cap a llevant.

Després, s'anirà (per aquesta mateixa carretera) cap al poble de Calders. Una mica més enllà del qual, a l'Estació de Servei de Calders, es farà una nova parada. A continuació, es continuarà cap a llevant, seguint sempre la carretera nacional N-141c, tot anant cap a la vila de Moià, que caldrà sobrepassar per tal d'agafar el camí que ens conduirà cap a l'antic poble de Ferrerons, per on es pot fer una nova aturada, si s'escau.

Tot seguit, després de retornar a la carretera N-141c, ens caldrà seguir cap a llevant, fins arribar al trencall d'on eix la carretereta que va cap a les Coves del Toll i de la Toixonera, on efectuarem una nova aturada. Aquest camí, degudament senyalitzat, surt per la dreta de la carretera que anem seguint des de Manresa.

Després de fer la darrera aturada, caldrà retornar a la via N-141c, per tal de continuar una mica més cap a ponent. Així s'arribarà a la població de Collsuspina, sobrepassant-la, per tal d'arribar fins al Port de la Pullosa, prop d’on es farà una nova aturada.

A continuació es baixarà cap avall, per tal d'arribar a les antigues guixeres situades per sobre de la carretera. En aquest indret finalitzarà el recorregut de l'itinerari.

\section{DESCRIPCIÓ DE L'ITINERARI}

Com ja es habitual, s'estructurarà en una sèrie d'estacions (parades o aturades), en les qual es faran descripcions geològiques o mineralògiques, segons s'escaigui. En cada cas s'indicarà el número del mapa topogràfic a escala 1:50.000 on es troba l'indret. En aquest cas, el recorregut de l'itinerari passarà per part dels dos següents fulls: $\mathbf{3 3 2}$ (dit de Vic) i $\mathbf{3 6 3}$ (o de Manresa), del IGC espanyol, a escala 1:50.000.

Així doncs, la relació general de les aturades que composen el recorregut de l'íitinerari, és la següent:

PARADA 1. TURÓ DE BUFALVENT, (terme municipal de Manresa, comarca del Bages). (Full 363).

El recorregut del present itinerari s'inicía en aquest indret, situat a l'extrem més sudoccidental del Polígon Industrial de Bufalvent, ubicat per sobre del riu Cardener. Des d'aquest indret, es pot gaudir d'un immillorable punt d'observació sobre la vall del Riu Cardener, lleugerament encaixada entre els nivells grisencs de la Formació Tossa, constituïda aquí, en aquests indrets per alternances de gresos, calcolutites i calcàries sorrenques. 
Tot i així, en aquest lloc on ara som, també es fa clarament palesa la presència de llits de conglomerats i de microconglomerats, intercalats entre els nivells sorrencs. Uns i altres constitueixen uns indrets enlairats i acinglerats, sobre els quals ens trobem situats. També, per de sota on ara som, es poden veure algunes baumes, situades a les alternances entre els nivells calcolutítics i els més gresencs, excavats per sota d’aquests darrers.

Per d'altra banda, des d'aquest indret, i mirant cap a ponent, es pot veure com els materials rogencs de la Formació Artés (i que després tallarem), es situen per sobre dels acabats d'esmentar. Això es pot constatar clarament mirant el color dels camps de conreu. I, tanmateix, des d'aquest indret, també es poden observar els típics "relieves en cuesta", així com els relleus tabulars (lleugerament decantats cap al NW). desenvolupats entre aquests materials, com els que es veuen al Serrat de la Torre de Santa Caterina.

PARADA 2. LA FONT DE LES TÀPIES, (terme municipal de Calders, comarca del Bages, subcomarca del Moianès). (Full 363).

Després de realitzar la parada anterior, ens caldrà circular per la variant de Manresa, per tal d'agafar la carretera N-141c, en el seu sentit cap a Vic. Així, primer es passarà per Sant Fruitós de Bages, per Torruella de Baix i pel trencall de Navarcles. Tot seguit, s'arribarà al trencall d'on surt (per la dreta) la carretera que se'n va cap a la Colònia Jorba. Just davant d'aquesta cruïlla, però per l'esquerra de la carretera surt un camí de terra, que ens caldrà agafar.

Per aquest camí, en ocasions molt dolent, aviat es trobarà el trencall que se'n va cap a la Casa de les Tàpies; i tot seguit el camí que surt per l'esquerra (com l'anterior), que se'n va cap a la Font de les Tàpies. Caldrà agafar-lo, i deixar aviat el cotxe, per tal de baixar a peu cap a la font. En arribar-hi, després de recórrer uns $13^{\prime} 5 \mathrm{Km}$, des de la darrera parada, ens caldrà fer la present.

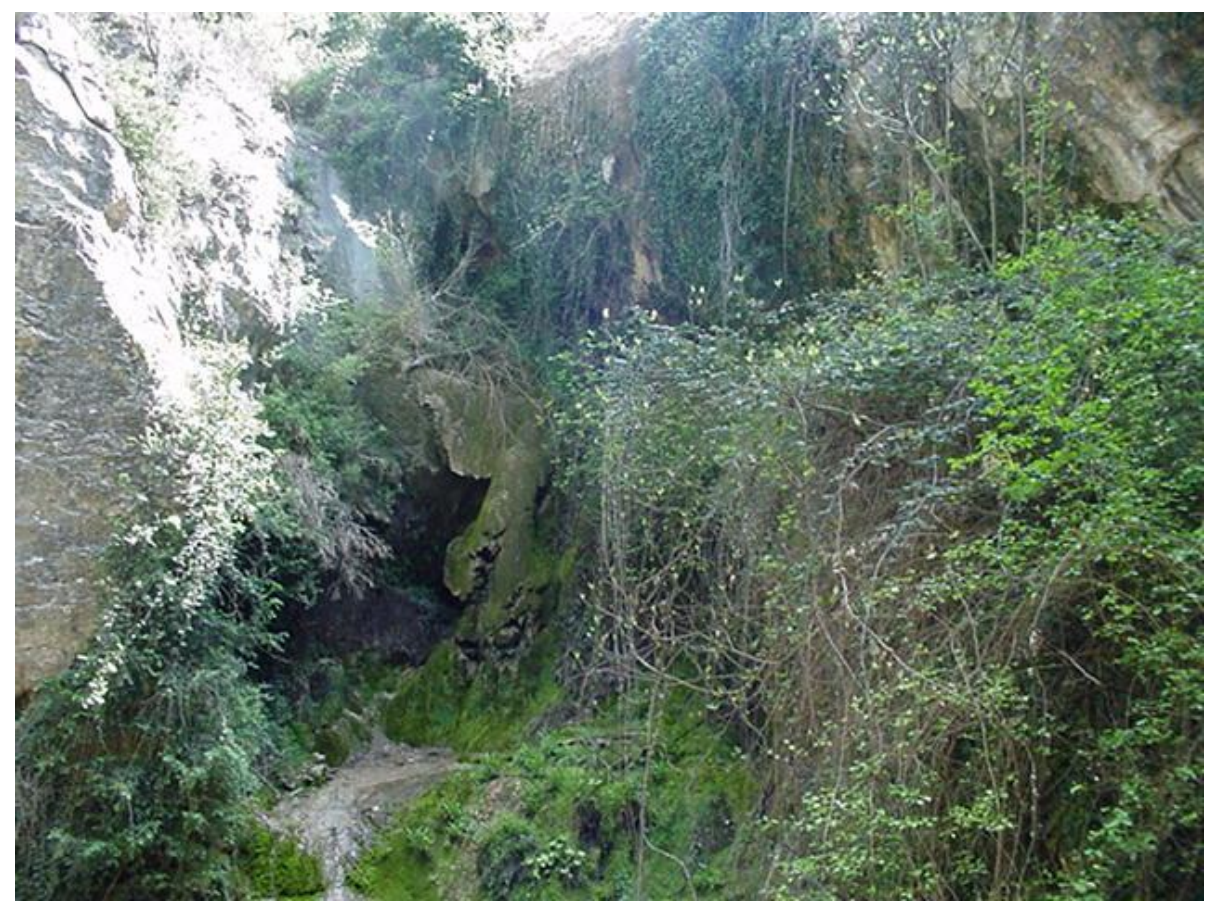

FOTOGRAFIA 1 (PARADA 2)

Detall de la Font de les Tàpies 
En aquest recorregut, en un principi s' han tallat els materials de la Formació Tossa, que ja hem vist a la parada anterior, sols que cada cop són menys detrítics i més carbonatats. Després, en arribar a la barriada del Guix (de Manresa), hem començat a trobar uns materials rogencs de la Formació Artés, constituïts per nivells de calcolutites i de gresos. Més endavant, en passar el trencall de Navarcles, hem tornat a tallar els nivells carbonatats de la Formació Tossa, que són els materials que apareixen per aquests indrets.

Aquí, a la Font de les Tàpies, hi ha una interessant surgéncia, i una cascada del Riuet de les Tàpies, que ha conduït a la formació d'un encaixat gorg. L'aigua que dona lloc a la font, procedeix d'una circulació Kàrstica entre els nivells de la Formació Tossa, que aquí es troben constituïdes per calcàries noduloses, coral-lines. Com a conseqüència de la surgència, s'han originat unes interessants formacions travertíniques, de gran bellesa.

Finalment, cal dir que aquest és un dels indrets seleccionats per a formar part del futur Parc Geològic $i$ Miner de la Comarca del Bages (MATA-PERELLÓ, 2004) i MATAPERELLÓ et altri (2006). Es tracta d'un dels PIG (Punts d'Interès Geològic) més importants de la Catalunya Central.

PARADA 3. FORN DE CALÇ DEL PLA DE LES QUINGLES, (terme municipal de Calders, comarca del Bages, subcomarca del Moianès). (Full 363).

Des de la parada anterior, cal retornar al camí, continuar-lo recorrent cap l'Est, per tal d'anar cap al Pla de les Quingles, i cap al Forn de Calç. En arribar-hi, caldrà fer una nova aturada, a uns 1’2 Km de la Font de les Tàpies.

En tot aquest recorregut, el camí va sempre circulant per entre els nivells carbonatats de la Formació Tossa, que ja hem trobat a la parada anterior. Precisament, en arribar al Pla de les Quingles, hem trobat una antiga explotació de calcàries, destinada al proper Forn de Calç. FOTOGRAFIA 2, a la página següent).

Aquest indret, es un important PIMP (Punt d’Interès del Patrimoni Miner) de la Comarca del Bages

\section{PARADA 4. CRUÏLLA DEL CAMÍ DEL PLA DE LES QUINGLES / CARRETERA D’ARTÉS, (terme municipal de Calders, comarca del Bages, subcomarca del Moianès). (Full 363).}

Des de la parada anterior, cal retornar al camí, continuar-lo recorrent cap l'Est, per tal d'arribar fins a l'origen del camí, i a la seva cruilla amb la carretera local B-431, la qual els pobles d'Artés i de Calders. Just en arribar a la cruilla, i després de recórrer uns 1’3 Km des de la parada anterior, ens caldrà fer aquesta aturada.

En tot aquest recorregut, el camí va sempre circulant per entre els nivells carbonatats de la Formació Tossa, que ja hem trobat a la parada anterior.

Finalment, en arribar a l'indret de l'aturada, es pot gaudir d’una immillorable visió dels 
materials que constitueixen la Depressió Geològica de l'Ebre, al Nord de l'indret on ara som. Tanmateix, des d'aquest lloc es pot gaudir de la visió del Prepirineu. I, tanmateix es poden observar les escombreres (el runam) de les mines de potassa de Sallent.

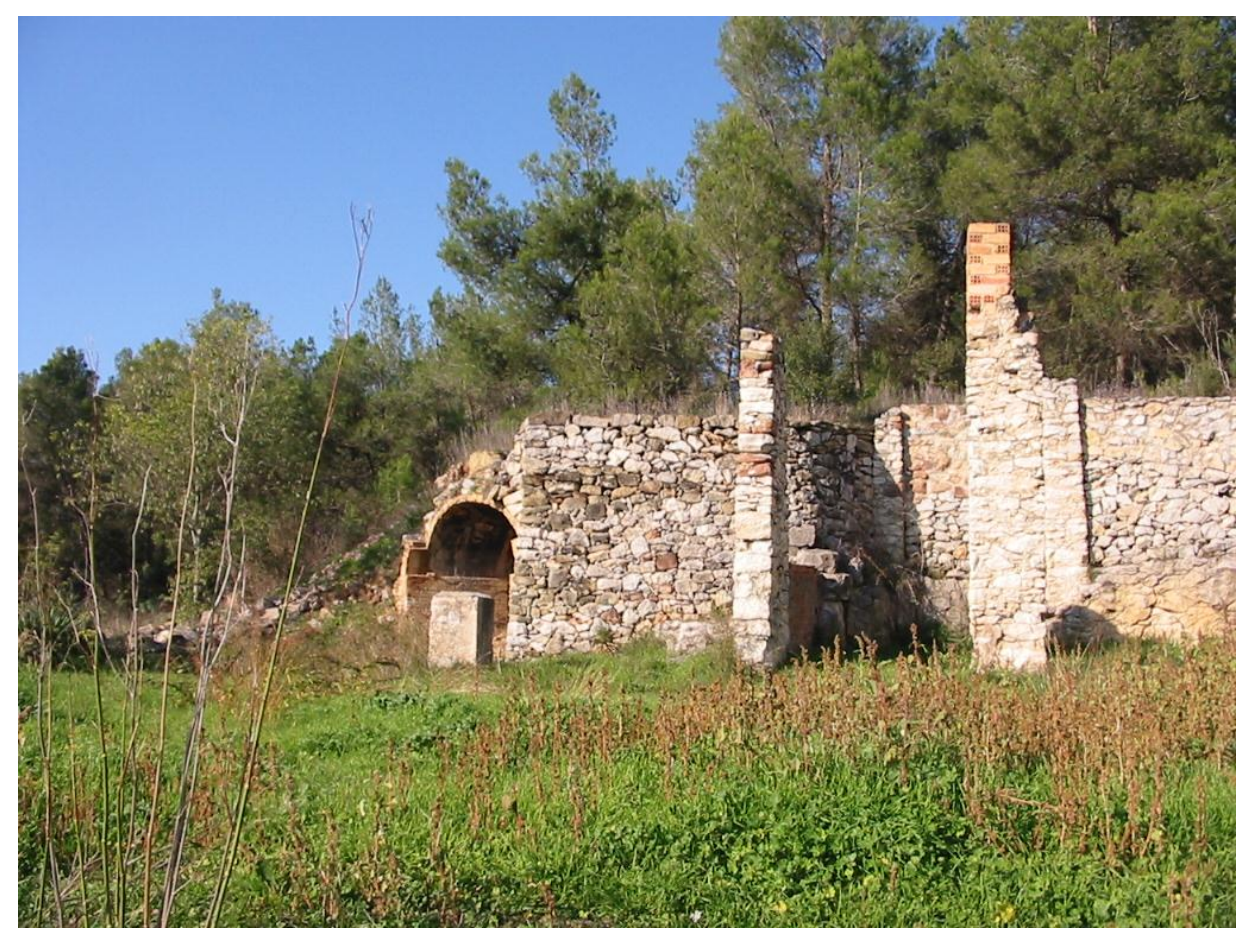

FOTOGRAFIA 2 (PARADA 3)

Detall del Forn de Calç del Pla de les quingles

PARADA 5. MEANDRE DEL RIU CALDERS, (la Guàrdia de Calders, terme municipal de Calders, comarca del Bages, subcomarca del Moianès). (Full 363).

Des de la parada anterior, cal seguir cap a Calders, per la carretera B-431, procedent d'Artés. Quasi en arribar a l'entrada del poble, pot agafar-se un camí que se'n va cap a la Guàrdia de Calders, per tal d'arribar a la carretera N-141c. En arribar-hi, ens cal cap al Km 15'8, desplaçant-nos lleugerament cap a llevant. Aquest indret es troba ubicat prop de la urbanització abans anomenada, la qual pertany al terme municipal del proper poble de Calders. Així, des de l'indret anterior de la parada anterior, s' hauran recorregut uns $5 \mathrm{Km}$.

En aquest recorregut, igual que hem fet abans, ens haurem anat desplaçant per entre els materials carbonatats de la Formació Tossa, tot i que en algun moment s'han fet palesos els nivells rogencs de la Formació Artés.

Pel que fa a l'indret concret de l'aturada, cal dir que el situarem a uns 25 metres, cap al Sud de la carretera, per sobre d'un penya-segat que domina la propera vall del Riu Calders. Des d'aquest indret, hi ha un immillorable punt d'observació sobre el "meandre del riu Calders". Per d'altra banda, en aquest lloc, hi ha uns plafons explicatius de la Diputació de Barcelona i de l'Ajuntament de Calders. Aquests plafons expliquen, entre altres aspectes, la formació i l'evolució de l'esmentat meandre. 
Precisament, des d'aquest lloc immillorable, es pot veure molt bé el meandre abandonat, amb el Castell de Calders enturonat al mig; i amb l’àntic Molí situat al saltant de l'engorjament del meandre.

Per d'altra banda, aquest punt d'observació es troba situat sobre un aflorament de les calcàries noduloses que pertanyen a la Formació Tossa, de fàcies recifal Aquestes calcàries constitueixen un interessant escull coral·lí, amb abundants restes fòssils: foraminífers, coralls, equinids, lamelibrànquis, gasteròpods, que es poden recollir principalment a la carretera que des de Calders va a Monistrol de Calders.

També és interessant observar el "relieve en cuesta" que ofereixen aquests nivells calcàris, tot mirant des de la carretera cap al meandre. I tanmateix, es poden veure algunes "baumetes", similars a les que hem vist a la primera aturada del recorregut. FOTOGRAFÍA 3.

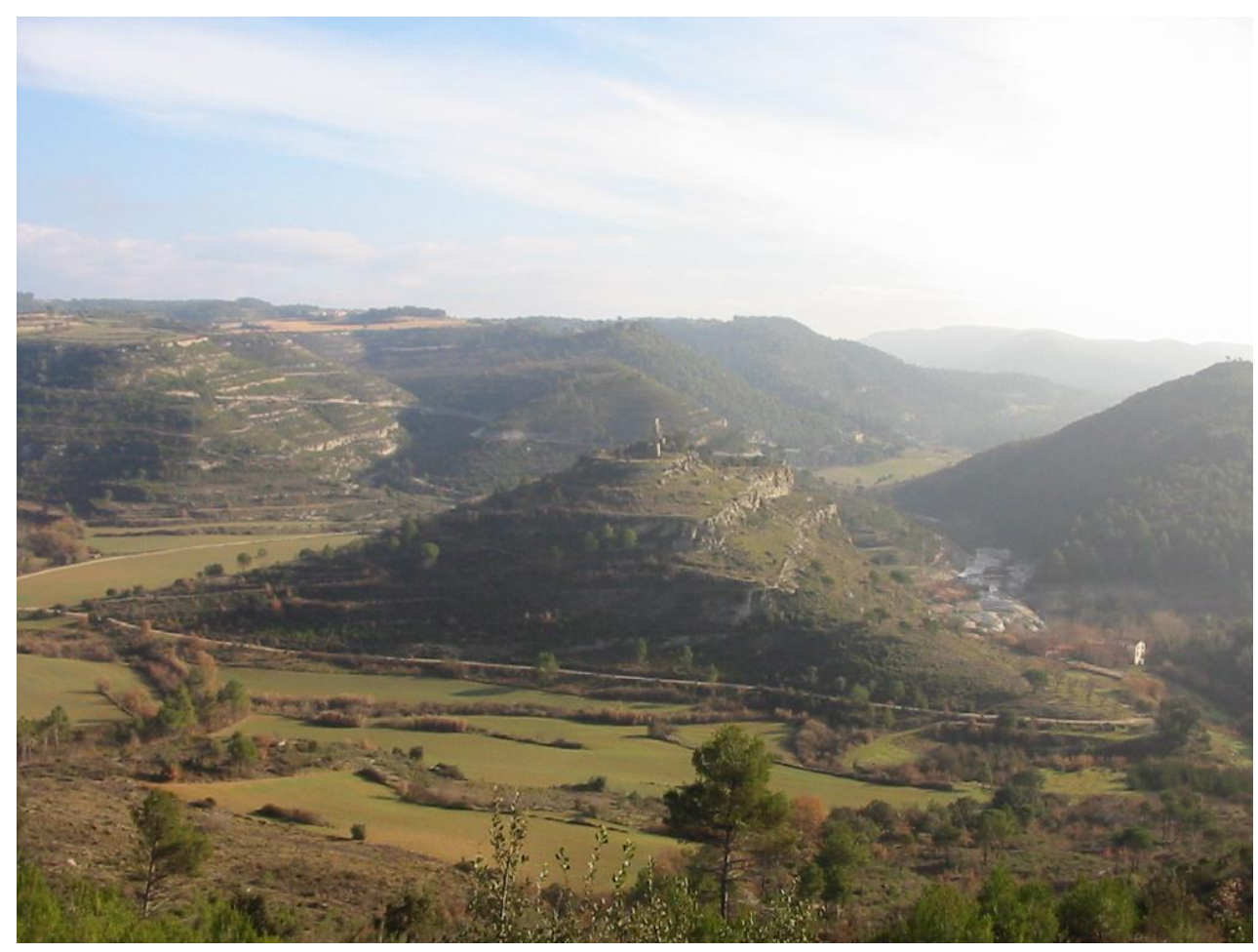

FOTOGRAFIA 3 (PARADA 5).

Detall, des del mirador de la Guàrdia, del meandre abandonat de Calders, del riu Calders

PARADA 6. ESTACIÓ DE SERVEI DE CALDERS, (terme municipal de Calders, comarca del Bages, subcomarca del Moianès). (Full 363).

Des de la parada anterior, cal continuar per la carretera N-141c tot anant cap a Calders. A uns $2^{\prime} 5 \mathrm{~km}$ de la parada anterior (i a $1 \mathrm{Km}$ del poble), es troba 1'Estació de Servei de Petrocat, situat a l’esquerra de la carretera, i ben a prop del seu Km 22. Aquí farem l'aturada.

En aquest recorregut, poc després de passar la cruïlla de la carretera a Monistrol de Calders i a Artés (la carretera B-431), es comencen a tallar els nivells rogencs de les calcolutites i dels gresos de la base de la Formació Artés. La carretera va seguint, en la seva major part 
d'aquest trajecte, el contacte entre aquests materials continentals i els marins de la Formació Tossa, que ja hem trobat a les tres darreres parades.

Ara, en aquest lloc, i mirant cap al nord, cap a la vall de la Riera de Malrubí, es pot gaudir d'un bon punt d’observació. Així, es pot observar com les calcolutites gris-blavoses de la Formació Igualada formen el fons de la vall. I com per sobre d'aquests materials, apareixen els de la Formació Tossa, formats per calcàries recifals (cap a l'est) i per nivells de guixos (cap a l'oest). I, també es pot observar, com tots aquests materials es troben recoberts pels nivells rogencs de les calcolutites de la Formació Artés, que formen ja tots els relleus septentrionals de la comarca del Bages i del Moianès.

També, des d'aquest indret, en dies de bona visibilitat, es pot gaudir d'un immillorable lloc d'observació, tant del Sistema Pirinenc (fent-se palesos els relleus del Puigmal, Puig Pedrós, Tossa d'Alp, Rasos de Peguera, Serra del Verd, Port del Compte, Cadí, Montsec,...), com dels sectors septentrionals de la pròpia Depressió Geològica de l'Ebre, on ara som (Lluçanès, Berguedà, Solsonès ...).

\section{PARADA 7. LA COVA DEL TOLL, (terme municipal de Moià, comarca del Bages, subcomarca del Moianès). (Full 364).}

Des de la parada anterior, cal continuar cap a Moià, des d'on caldrà continuar cap a 1’Est, seguint sempre la carretera N-141c. Més endavant després de sobrepassar unes corbes, cap a les immediacions del $\mathrm{Km} \mathrm{31}$, , es trobarà un altre trencall però ara per la dreta de la carretera. Aquest trencall, ens conduirà, en 1'5 Km, primer cap a la Cova del Toll, i després (en uns 200 m) cap a la Cova de les Toixoneres. Cal dir que el trencall es troba correctament senyalitzat. En arribar a la primera cova, caldrà fer la present aturada, després de recórrer uns $7 \mathrm{Km}$, des de la parada anterior.

Des de la parada anterior, s'ha anat circulant sempre pels nivells calcolutítics i gresencs rogencs, de la Formació Artés, però prop del contacte amb els nivells carbonatats de la Formació Tossa, que en molts llocs es fan palesos a la bora da la carretera.

Tot i així, prop de la Cova del Toll, s'han començat a tallar de nou les calcàries noduloses que pertanyen a la Formació Tossa. Aquestes darreres són les que es troben als dos indrets de la present aturada. Tant la Cova del Toll, com la Cova de les Toixoneres, es troben situades sobre els nivells carbonatats de la Formació Tossa. FOTOGRAFIA 4 (a la página següent).

Ambdues formen part del mateix aparell kàrstic, trobant-se comunicades entre sí. A l'actualitat no es pot penetrar a la primera de les coves, sense autorització, doncs es troba en fase de recerca, en haver-se trobat abundants restes fòssils de vertebrats, corresponents al Paleolític Inferior. A l'actualitat, per tal de visitar-la, es poden contractar els serveis immillorables del Museu de Moià.

Pel que fa a la Cova de les Toixoneres, situada a uns $100 \mathrm{~m}$ de la primera, tot anat barranc avall a peu. Actualment s'estan realitzant recerques. Per d'altra banda, a uns $100 \mathrm{~m}$ d'aquesta es troba l'eixida de l'aigua de la Cdova del Toll, on es possible de entrar, però degudament equipats, doncs aquesta cova correspon a la surgència del Toll, i conseqüentment es troba ocasionalment inundada. FOTOGRAFIA 5 (a la página següent). 


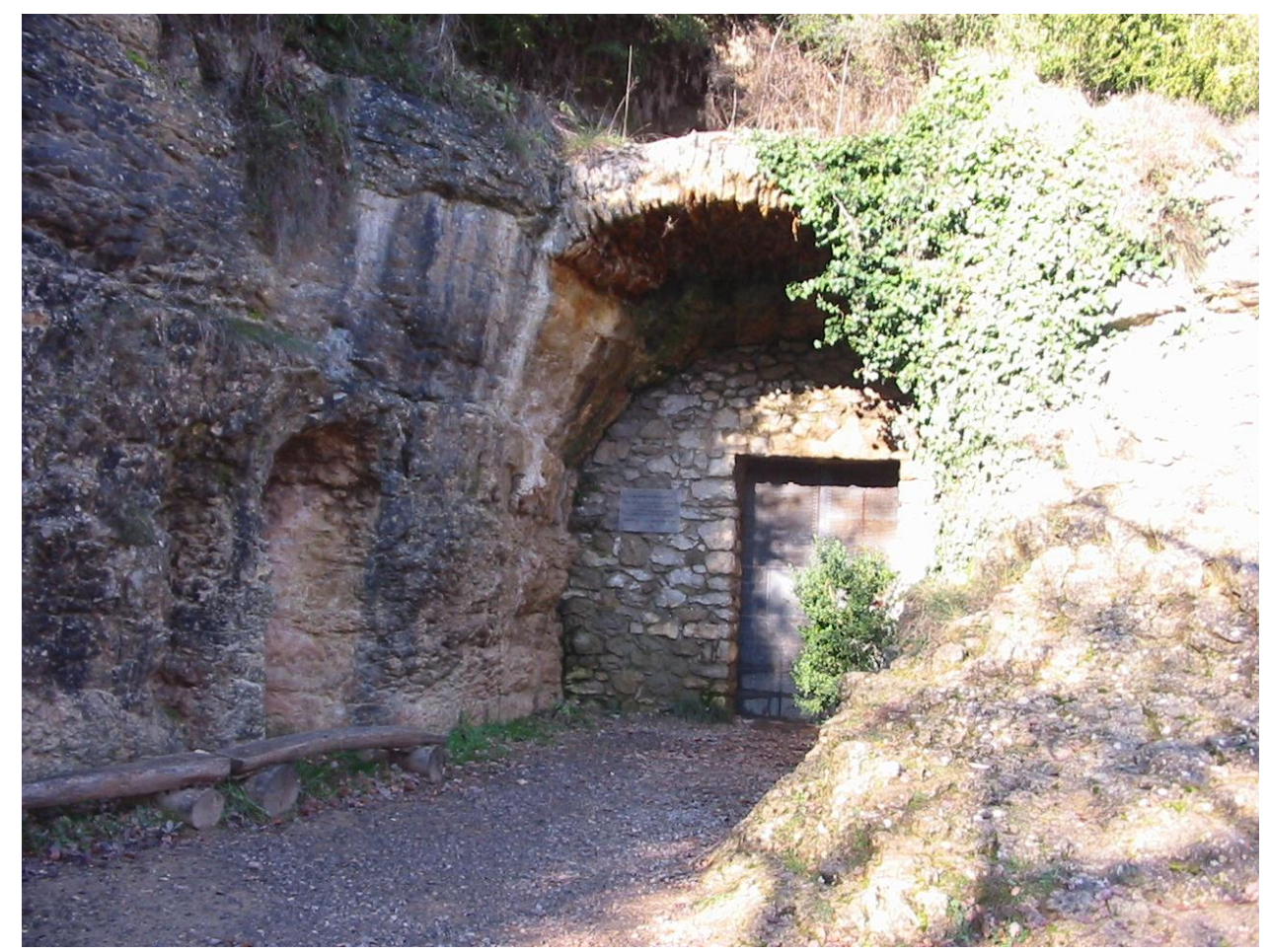

FOTOGRAFIA 4. (PARADA 7).

Detall de l'entrada a la Cova del Toll

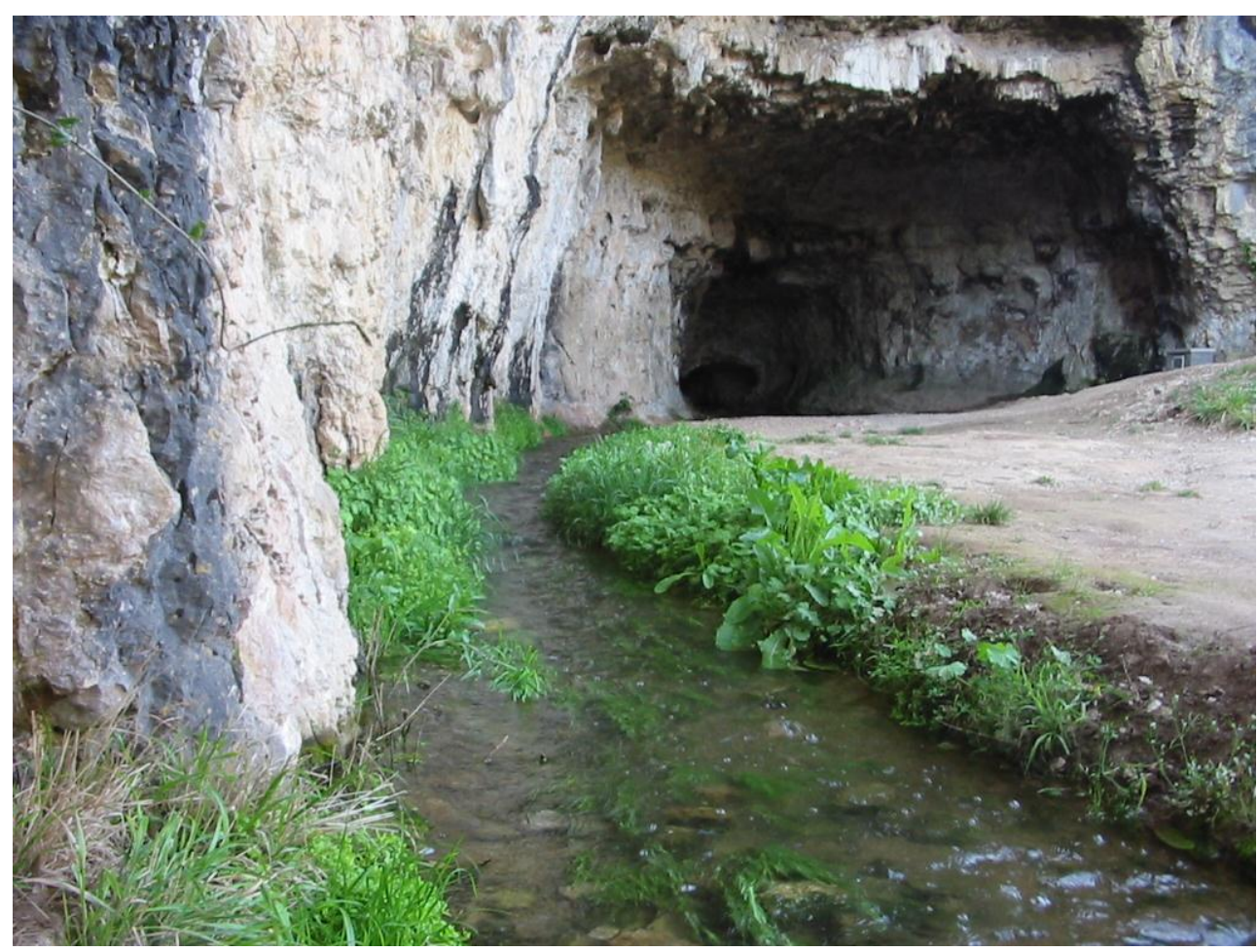

FOTOGRAFIA 5 (PARADA 7).

Detall de la surgència d'aigua de la Cova del Toll

Finalment, cal dir que tot aquest conjunt es un indret molt interessant del Patrimoni 
Geològic de la Catalunya Central. Per d'altra banda el recorregut entre les dues coves permet fer un interessant recorregut de natura, molt ben senyalitzat i didàctic

PARADA 8. MIRADOR DE SANT CUGAT DE GAVADONS, (terme municipal de Collsuspina, comarca d'Osona; subcomarca del Moianè). (Full 364).

Des de la parada anterior, ens cal retornar a la carretera N-141c, per tal de continuar cap a Collsuspina. En arribar al poble. Trobarem per l'esquerra el trencall de Sant Cugat de Gabadons, on ens caldrà anar, fent un recorregut d'uns 2'5 Km des del trencall i d'uns 7 Km des de la parada anteriorment realitzada.

En tot aquest recorregut, s'han tallat inicialment els materials carbonatats de la Formació Tossa; però ben aviat s' han tornat a trobar els nivells rogencs de calcolutites i gresos de la Formació Artés, circulant sempre prop del contacte entre ambdues formacions.

Des d'aquest indret es pot gaudir d'un immillorable lloc d'observació. Així, mirant cap al SE es pot veure el Montseny (de la Serralada Prelitoral Catalana), mirant cap a l'Est es pot veure l'extensa Plana de Vic i tanmateix el Cabrerés (de la Serralada Transversal). Mirant cap al Nord i cap al NE es pot veure amplament el Sistema Pirinenc.

PARADA 9. LA PULLOSA, TRENCALL DEL PUIG CASTELLÀ, (termes de Collsuspina i de Balenyà, comarca d’Osona; i també de la subcomarca del Moianès el primer terme). (Full 364).

Des de la parada anterior, ens cal retornar a la cruïlla de Collsuspina, per tal de continuar per la carretera N-141c,. Poc després de passar el poble s'arriba al Port de la Pullosa, i tot seguit es comença a baixar. En arribar al trencall de la carretera que es dirigeix cap al Puig Castellar, cal fer una parada. Així, des de la parada anterior s'ha fet un recorregut aproximat de prop de 3 $\mathrm{Km}$.

Com al tram anterior, en tot aquest recorregut, s'han tallat inicialment els materials carbonatats de la Formació Tossa; però ben aviat s han tornat a trobar els nivells rogencs de calcolutites i gresos de la Formació Artés, circulant sempre prop del contacte entre ambdues formacions.

En arribar a l'indret de la parada, alhora de sobrepassar el Port de la Pullosa, s'han estat tallant els nivells rogencs abans esmentats; mentre que on ara som ens trobem sobre els nivells de la Formació Tossa, que ara són molt més detrítics que a la Cova del Toll, dons hi ha nivells carbonatats com abans, però també n'hi ha de gresos grisencs amb filades de microconglomerats.

Des d'aquest indret es pot gaudir d'un bon lloc d'observació de la Plana de Vic, situada al peu de la Serralada Prelitoral del Sistema Mediterrani), en concret dels seus sectors de les Guilleries i del Montseny. Així, es poden veure els extensos afloraments dels nivells de calcolutites gris-blavoses, que pertanyen a la Formació Igualada, i que es constitueixen les planes situades als peus d'on ara ens trobem. 
També s'observa com aquests materials son recoberts pels nivells dels guixos de la Noguera (equivalents als guixos d'Òdena, de la Formació Tossa). Igualment s'observa el recobriment de tots aquests materials per part de les calcolutites i dels gresos rogencs, de la Formació Artés. Aquests darrers ja formen els relleus de la Serra de 1’Oller.

Igualment mirant cap a l’Est, es poden divisar els relleus del Cabrerès, els quals formen part de la denominada Serralada Transversal, una important alineació de direcció NNW-SSE, limitada per un conjunt de falles, que van esfondrar la Depressió Geològica de l'Ebre, cap a llevant. Cal remarcar que la direcció d'aquestes alineacions, és similar a la falla de la Fàbrega, que hem trobat en el trajecte cap a la parada anterior. Finalment, des d'aquest indret del Port de la Pullosa, o des de les antigues guixeres, es pot veure un interessant exemple de "relieve en cuesta" desenvolupat sobre els materials anteriors.

PARADA 10. GUIXERES DE TONA, (terme municipal de Tona, comarca d'Osona). (Full 332).

Des de la parada anterior, hi ha la possibilitat de baixar per la carretera N-141c, per tal d'arribar a la plana on es troba la cruilla amb la carretera que se'n va cap a Tona. Abans d'arribar-hi, es troben diversos trencalls que se'n van cap a les antigues Guixeres de Tona, situades per sobre de la carretera. Un d'aquests camins surt de les immediacions del Km 38`3.

Cal dir que les esmentades guixeres es troben situades sobre afloraments de la Formació Tossa (constituint els denominats guixos de la Noguera). Entre els guixos es troben els següents minerals: ANHIDRITA, GUIX (el més abundant) i HEMIHEDRITA. També es troben presents la CALCITA i la CAOLINITA.

Per sobre de les guixeres es fan clarament palesos els nivells rogencs de la Formació Artés, entre els quals més amunt es veuen els trams carbonatats de les calcàries de Moià, de les que hem parlat anteriorment en altres parades. Un esquema d'aquests afloraments dels nivells de guixos de la Formació Tossa (guixos de la Noguera), és el següent:

Per d'altra banda, cal dir que en aquest indret es troben diverses guixeres, tot i així no n'hi ha cap en explotació, de fa força anys. Malgrat això, prop d'aquest indret, però al terme de Santa Eulàlia de Riuprimer, encara n'hi ha d'actives.

\section{EN AQUEST INDRET FINALITZA EL PRESENT ITINERARI}

\section{REFERÈNCIES BIBLIOGRÀFIQUES}

BARNOLAS, A. et altri (1986).- Mapa Geológico de España a escala 1:50.000. Hoja y explicación nº 332 (Vic). Ins. Geol. Mi. España. Minist. Indústria y Energia. Madrid 
BUSQUETS, P. et altri (1979).- Geologia d'Osona, Publicacions de l'Escola Universitària de Mestres d'Osona. Vic

COLLDEFORNS, B. (1986).- Estudi Geològic de la comarca del Bages. Public. EUPM, 399 pàgines. Manresa

GUIMERÀ, J. et altri (1992).- Geologia (II), Història Natural dels Països Catalans, Vol. 2, 547 pag. Enciclopèdia Catalana, S.A. Barcelona

IGME (1975).- Mapa Geológico de España a Escala 1:50.000 ( $2^{\mathrm{a}}$ Serie). Hoja y Memoria $\mathrm{n}^{\mathbf{o}}$ 363 (Manresa). Inst. Tecnológico y GeoMinero de España. Minist. Indus. Ener. Madrid.

IGME (1982).- Mapa Geológico de España a Escala 1:50.000 ( $2^{\mathrm{a}}$ Serie). Hoja y Memoria ${ }^{\circ}$ $\underline{332}$ (Vic). Inst. Tecnológico y GeoMinero de España. Minist. Indus. Ener. Madrid.

MASACHS, V. et altri (1981).- Itineraris geològics per Anoia, Bages, Berguedà i Solsonès. Pub. Caixa d'Estalvis de Manresa, 205 pag. Manresa

MATA-PERELLÓ, J,M. (1986).- Depressió Geològica de 1’Ebre, o Depressió Central Catalana?. Revista Dovella, no 35, pp. 85-90, Manresa

MATA-PERELLÓ, J.M. (1991).- Els Minerals de Catalunya. Arxius de la Secció de Ciències, t. XCIII, Institut d'Estudis Catalans. Barcelona

MATA-PERELLÓ, J.M. (1996).- Itinerari Geològico-Mineralògic pel Bages, pel Moianès i per Osona: des de Sant Fruitós de Bages a Collsuspina i a Taradell. Inèdit, 10 pàgines. Manresa

MATA-PERELLÓ, J.M. (1997).- Recerca geològica i mineralògica per les comarques del Bages i del Moianès: des de Manresa a Collsuspina i a Muntanyola, per Calders i per Artés. Inèdit. 16 pàgines. Manresa

MATA-PERELLÓ, J.M. (1999a).- Itinerari geològic i mineralògic per la comarca del Bages: des de Manresa a Collsuspina, i des de Ferrerons a Avinyó. Inèdit. 12 pàgines. Manresa

MATA-PERELLÓ, J.M. (1999b).- Recorregut de recerca geològica i mineralògica per les comarques del Bages, del Moianès i d’Osona: des de Manresa a Moià i a Tona. Algeps, sèrie B, $\mathrm{n}^{\circ} 116,14$ pag. Manresa

MATA-PERELLÓ, J.M (2000).- Recorregut de recerca geològica i mineralògica per les comarques del Bages, del Moianès i d'Osona: des de Manresa a Moià, Tona i Viladrau, Inèdit, 19 pàg. Manresa

MATA-PERELLÓ, J.M (2004).- El Parque Geológico de la Comarca del Bages (Parc Geològic de la Comarca del Bages), Depresión Geológica del Ebro, Catalunya Central. Actas del V Congreso Internacional sobre Patrimonio Geológico y Minero. Pp. 10. Utrillas

MATA-PERELLÓ, J.M. (2005).- Recorregut de recerca geològica i mineralògica per les comarques del Bages i del Moianès: des de Manresa a Moià i a Collsuspina. Inèdit. 10 pag. Manresa

MATA-PERELLÓ, J.M. (2006).- Recorregut de recerca geològica i mineralògica per les 
comarques del Bages, del Moianès i d'Osona: des de Manresa a Moià, Collsuspina i a Tona. Inèdit.14 págines. Manresa

MATA-PERELLÓ, J.M. (2008).- Recorregut de recerca geològica i mineralògica per les comarques del Bages i del Moianès: des d'Artés a Calders, Moià i a les Coves del Toll. Inèdit.14 págines. Manresa

MATA-PERELLÓ, J.M. (2008).- Recorregut de recerca geològica i mineralògica per les comarques del Bages, del Moianès i d’Osona: des de Manresa a Moià, Collsuspina i a Tona. Inèdit. 14 pag. Manresa

MATA-PERELLÓ, J.M (2005 et altri).- El Ordenamiento Territorial de la Cuenca Potásica Catalana. Depresión Geológica del Ebro, Catalunya Central. Jornadas de la RED CYTED - XIII en Cusco, enero del 2006. Inédito. 12 pág. Cusco

MATA-PERELLÓ, J.M. i COLLDEFORNS, B. (1988).- Inventari Mineralògic de la comarca del Bages, Xaragall, nº 23, 32 pagines. Manresa

MATA-PERELLÓ, J.M; MELGAREJO, J.C. i SOLER, A. (1986).- Inventari Mineralògic de la comarca d’Osona. Xaragall, 15. Manresa

MATA-PERELLÓ, J.M. i SANZ BALAGUÉ, J. (1988).- Guia d'Identificació de Minerals (Països Catalans i d'altres). Edit. Parcir, 205 pag. Manresa

RIBA ARDERIU, O. (1967).- Resultado de un estudio sobre el terciario continental de la parte Este de la Depr. Central. Acta Geol. Hispánica, t. II, nº 1. pp. 3-4. Barcelona

RIBA ARDERIU, O. Et altri. (1976).- Geografia física dels Països Catalans. Edit Ketres. Barcelona 